\title{
Mikroprocesorowy układ sterowania zespołem wentylacyjno - grzewczym dla tramwaju
}

\begin{abstract}
$W$ artykule omówiono układ sterowania zespótem wentylacyjno-grzewczym typu 104ZW o mocy $20 \mathrm{~kW}$ przeznaczonym do wentylacji i ogrzewania wnętrza wagonu tramwaju. Zespót przystosowany jest do wspótpracy z dodatkowymi grzejnikami o tacznej mocy $10 \mathrm{~kW}$ umieszczonymi pod siedzeniami w przedziale pasażerskim oraz z wentylatorami dachowymi.. Do zasilania elementów grzejnych zarówno $w$ zespole wentylacyjno-grzewczym jak i elementów grzejnych $w$ wagonie a także wentylatorów oraz obwodów zabezpieczeń termicznych zastosowano taczniki tranzystorowe wykonane w IPS „TABOR”. Praca całego układu nawiewnego wagonu steruje sterownik mikroprocesorowy.
\end{abstract}

\section{Wstęp}

Wychodząc naprzeciw obecnym dążeniom do zwiększenia komfortu jazdy pasażerów komunikacji miejskiej, w Instytucie Pojazdów Szynowych „TABOR" wykonano projekt i prototyp zespołu wentylacyjno-grzewczego. Rozwiązanie oparte jest na technice mikroprocesorowej.

\section{Przeznaczenie}

Zespół wentylacyjno-grzewczy typu 104ZW o mocy $20 \mathrm{~kW}$ przeznaczony jest do wentylacji i ogrzewania wnętrza wagonu tramwaju. Zapewnia dopływ do przedziału pasażerskiego tramwaju świeżego powietrza w okresie letnim, a w okresie przejściowym i zimowym ogrzanej mieszaniny powietrza świeżego i recyrkulacyjnego.

Zespół przystosowany jest do współpracy z grzejnikami umieszczonymi pod siedzeniami w przedziale pasażerskim o łącznej mocy $10 \mathrm{~kW}$ oraz współpracuje $\mathrm{z}$ wentylacją wywiewną (dachową) realizowana przez dwa wentylatory dachowe, które odprowadzają na zewnątrz powietrze $\mathrm{z}$ wnętrza przedziału pasażerskiego.

\section{Budowa}

Zespół wentylacyjno-grzewczy ma budowę modułową. Skupione są w nim wszystkie elementy zabezpieczające i sterujące obwodów nie tylko samego zespołu ale również urządzeń z nim współpracujących.

Zespół składa się z następujących urządzeń pokazanych schematycznie na rysunku 1 :

1. skrzyni zespołu z dwiema odchylnymi górnymi pokrywami oraz z przepustnicami powietrza zewnętrznego i wewnętrznego,

2. zespołu grzałek z kanałami, wentylatorem i urządzeniami regulacyjnymi i zabezpieczającymi,

3. filtrów powietrza nadmuchiwanego,

4. skrzynki z urządzeniami wysokonapięciowymi,

5. skrzynki z urządzeniami $230 \mathrm{~V}$,

6. płyty z zamocowanymi urządzeniami elektronicznymi,

7. przyłączy:

- X1 - złącze WN DC

- $\quad$ X2 - złącze $230 \mathrm{~V}$ AC

- X3 - złącze 24V DC

- XW1 i XW2 są pomocniczymi złączami wewnętrznymi. 


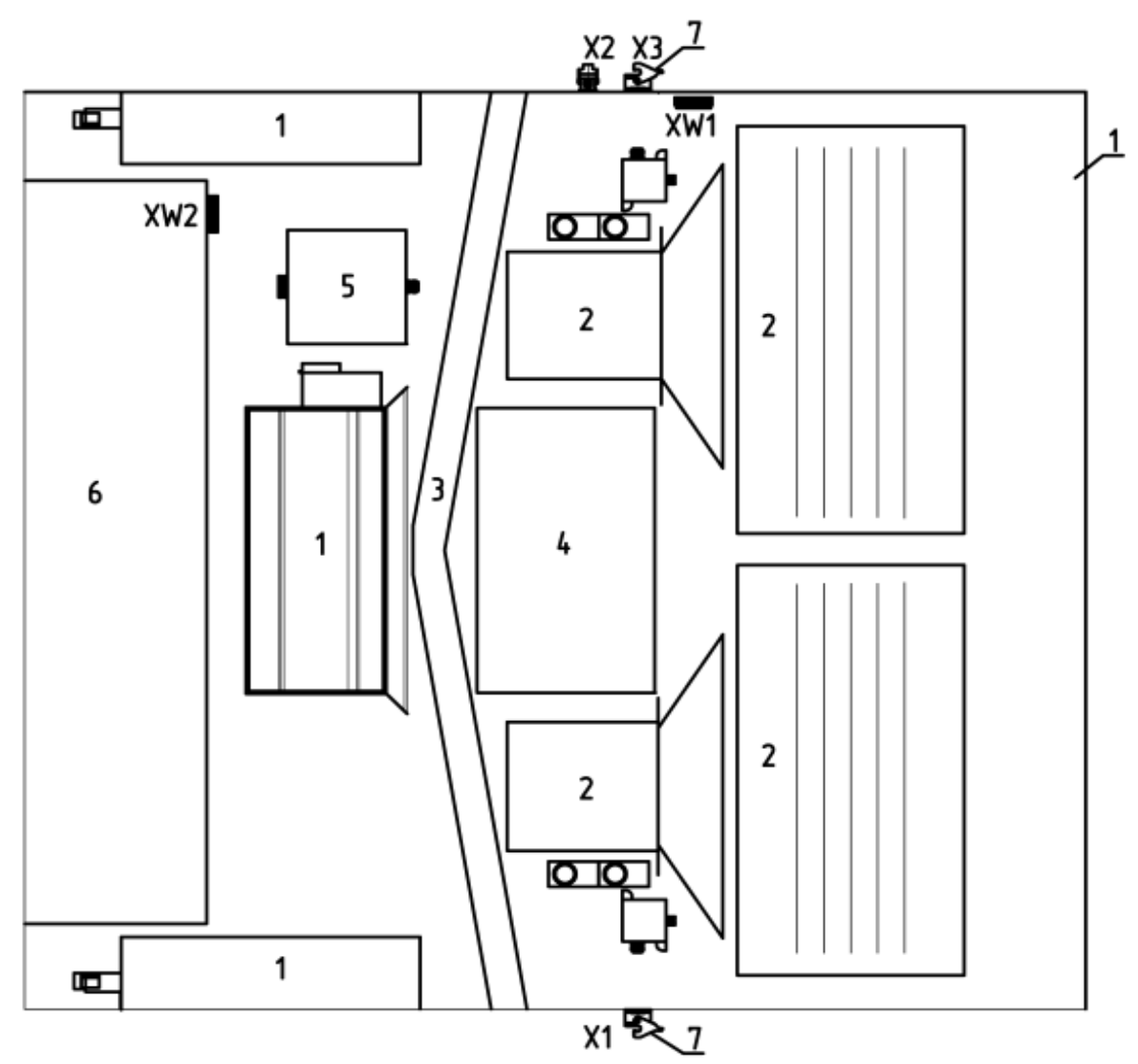

Rys. 1. Schemat poglądowy zespołu wentylacyjno-grzewczego

\section{Działanie}

Powietrze do zespołu wentylacyjno-grzewczego zasysane jest poprzez dwie przepustnice powietrza zewnętrznego i jedną przepustnicę powietrza powrotnego. Po przefiltrowaniu w filtrze wentylatory wdmuchuja powietrze do oddzielnych komór z nagrzewnicami powietrza i dalej do dwóch kanałów w suficie wagonu.

\section{Sterowanie}

Pracą układu nawiewnego wagonu, w tym również zespołem wentylacyjno-grzewczym, steruje umieszczony w nim sterownik mikroprocesorowy. Informacje o wybranym rodzaju pracy układu sterownik otrzymuje od trzech przełączników znajdujących się poza zespołem wentylacyjno-grzewczym:

- od nastawnika temperatury zadanej dla całego tramwaju; nastawnikiem tym motorniczy wybiera skokowo temperaturę nawiewanego powietrza

- od przełącznika wyboru ogrzewania górnego lub dolnego w każdym wagonie; przełącznik ten umożliwia motorniczemu załączenie elementów grzejnych w zespole wentylacyjno - grzewczym lub grzejników podsiedzeniowych lub załączenie obu odbiorów równocześnie

- od nastawnika zmiany obrotów wentylatorów w zespołach wentylacyjno-grzewczych tramwaju; nastawnikiem tym motorniczy może obniżyć wydajność wentylatorów.
$\mathrm{O}$ załączeniu elementów grzejnych w zespole wentylacyjno-grzewczym oraz elementów we wnętrzu wagonu decydują sygnały $\mathrm{z}$ czujników temperatury w samym zespole oraz w części pasażerskiej wagonu.

$\mathrm{W}$ oparciu o $\mathrm{w} / \mathrm{w}$ informacje sterownik wypracowuje sygnały sterujące pracą nagrzewnic, wentylatorów i przepustnic.

Wyróżnić można 4 następujące stany pracy:

- przewietrzanie

W stanie tym pracują wentylatory: w zespole wentylacyjno-grzewczym oraz wyciagowe a przepustnice powietrza zewnętrznego są całkowicie otwarte i przepustnica powietrza powrotnego jest zamknięta.

\section{- rozgrzewanie}

Stan ten występuje, gdy temperatura w otoczeniu grzałek w zespole jest niższa od nastawionej. Załączone są wtedy nagrzewnice w zespole, a wentylatory nawiewne $\mathrm{w}$ zespole $\mathrm{i}$ wyciagowe $\mathrm{w}$ wagonie są wyłączone. Wszystkie przepustnice w zespole są zamknięte.

\section{- nagrzewanie wagonu}

Stan ten występuje, gdy temperatura w otoczeniu grzałek osiagnie temperaturę zadaną a temperatura wewnątrz wagonu jest niższa od nastawionej. Cyklicznie załączane są wówczas nagrzewnice w zespole oraz pracują wentylatory nawiewne w zespo- 
1e. Wentylatory wyciagowe w wagonie są wyłączone. Przepustnice powietrza zewnętrznego w zespole są zamknięte, a przepustnica powietrza powrotnego jest całkowicie otwarta.

\section{- ogrzewanie cykliczne}

Stan ten występuje, gdy temperatura wewnątrz wagonu osiagnie temperaturę zadaną.

Cyklicznie załączane są wówczas nagrzewnice $\mathrm{w}$ zespole oraz pracują wentylatory nawiewne w zespole i wentylatory wyciagowe w wagonie. Przepustnice powietrza zewnętrznego $\mathrm{W}$ zespole są otwarte, a przepustnica powietrza powrotnego jest zamknięta.

Nagrzewnice pod siedzeniami w wagonie moga być załączone lub nie, zależnie od nastawienia rodzaju pracy przełącznikiem wyboru ogrzewania górnego i dolnego.

Każda nagrzewnica powietrza w zespole wentylacyjno-grzewczym (poz.2 na rys.1) jest ponadto zabezpieczona:

- termostatem o nastawie $50^{\circ} \mathrm{C}$, który wyłącza zasilanie nagrzewnicy po przekroczeniu tej temperatury i ponownie załącza zasilanie po obniżeniu się temperatury o $5^{\circ} \mathrm{C}$

- termostatem o nastawie $90^{\circ} \mathrm{C}$, który wyłącza zasilanie nagrzewnicy po przekroczeniu tej temperatury. Ponowne załączenie zasilania nagrzewnicy może nastąić po obniżeniu się temperatury o $8^{0} \mathrm{C}$ oraz ręcznym odblokowaniu przyciskiem znajdującym się na termostacie. Takie odblokowanie następuje w warunkach warsztatowych. Jednak przed ponownym załączeniem tego termostatu należy ustalić przyczynę jego zadziałania

- presostatem o nastawie 50Pa, który wyłącza zasilanie nagrzewnicy w przypadku obniżenia się ciśnienia nawiewanego powietrza poniżej tej wartości.

\section{Zastosowane elementy lączeniowe i wykonawcze 6.1 Łącznik ŁTW-800}

Do zasilania grzałek głównych nagrzewnicy o mocy $2 \times 10 \mathrm{~kW}$ oraz grzałek podsiedzeniowych o mocy $2 \times 5 \mathrm{~kW}$ zastosowano łączniki tranzystorowe $\mathrm{LTW}$ 800 opracowane dla potrzeb omawianej nagrzewnicy w IPS „TABOR”. Zastosowanie łączników bezstykowych zamiast styczników podnosi niezawodność, trwałość oraz zmniejsza poziom zakłóceń elektromagnetycznych. Ponadto umożliwia zastosowanie regulacji mocy przez zmianę współczynnika wypełnienia częstotliwości załączeń. Stąd wynika precyzyjniejsza regulacja mocy grzejników podsiedzeniowych niż ta wynikająca tylko z przełączania sekcji grzewczych. Nieograniczona ilość załączeń grzałek głównych daje dodatkową możliwość regulacji średniej mocy grza- nia. Łącznik ŁTW-800 (rys.2) skonstruowano w oparciu o wysokonapięciowe moduły IGBT.

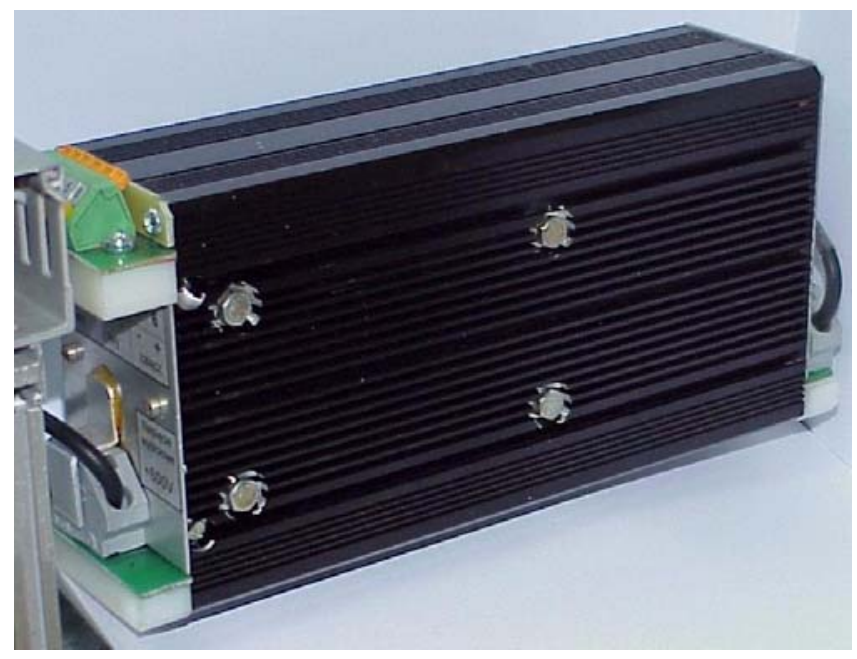

Rys.2. Widok łącznika ŁTW-800

Łącznik pracuje $\mathrm{w}$ zakresie temperatur od $-30^{\circ} \mathrm{C}$ do $+70^{\circ} \mathrm{C}$. Może załączać prąd do $20 \mathrm{~A}$ dla obciążeń o charakterze indukcyjnym przy napięciu do $850 \mathrm{~V}$, co daje maksymalną moc łączeniową $17 \mathrm{~kW}$. Łącznik posiada zabezpieczenie przeciwzwarciowe działające przy prądzie 30A. Ma ono charakter bezpiecznikowy, tzn. po jego zadziałaniu konieczne jest zdjęcie napięcia sterującego i ponowne jego załączenie. Ponadto łącznik ma wbudowany układ ograniczenia stromości narastania prądu do wartości $20 \mathrm{~A} / \mu \mathrm{s}$. Wymiary gabarytowe wynoszą $236 \times 60 \times 106 \mathrm{~mm}$. Obudowa jest przystosowana do montażu 4 śrubami M4 o rozstawie $62 \times 130 \mathrm{~mm}$. Wszystkie podzespoły elektroniczne znajdujące się wewnątrz obudowy są zalewane kauczukiem silikonowym. Przykładowe przebiegi prądów przy załączaniu obciążenia oraz załączania na zwarcie przedstawiono na rys.3,4 i 5.

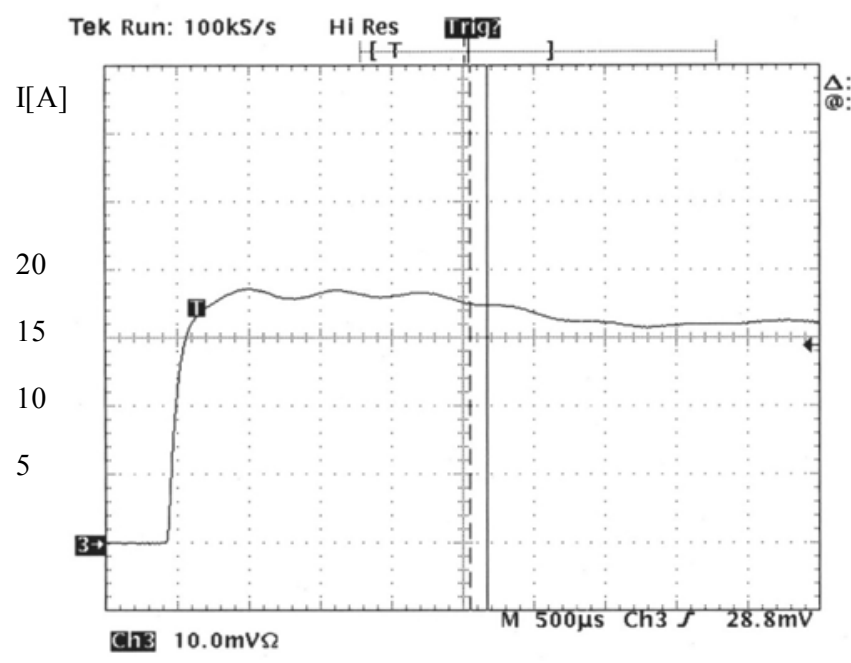

Rys. 3. Prąd przy załączaniu obciążenia $11 \mathrm{~kW}$ (5A/dz.) 


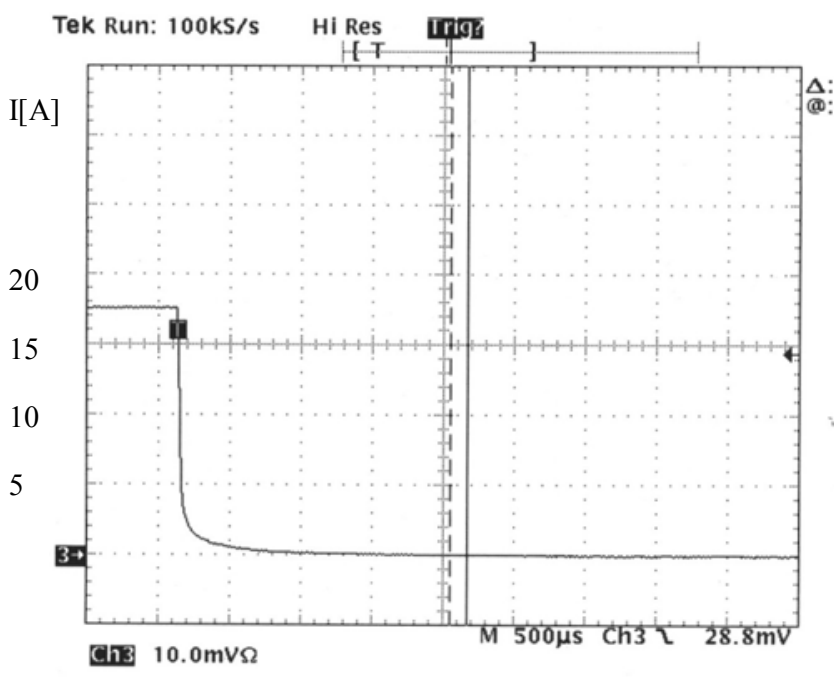

Rys. 4. Prąd przy wyłączaniu obciążenia $11 \mathrm{~kW}$ (5A/dz.)

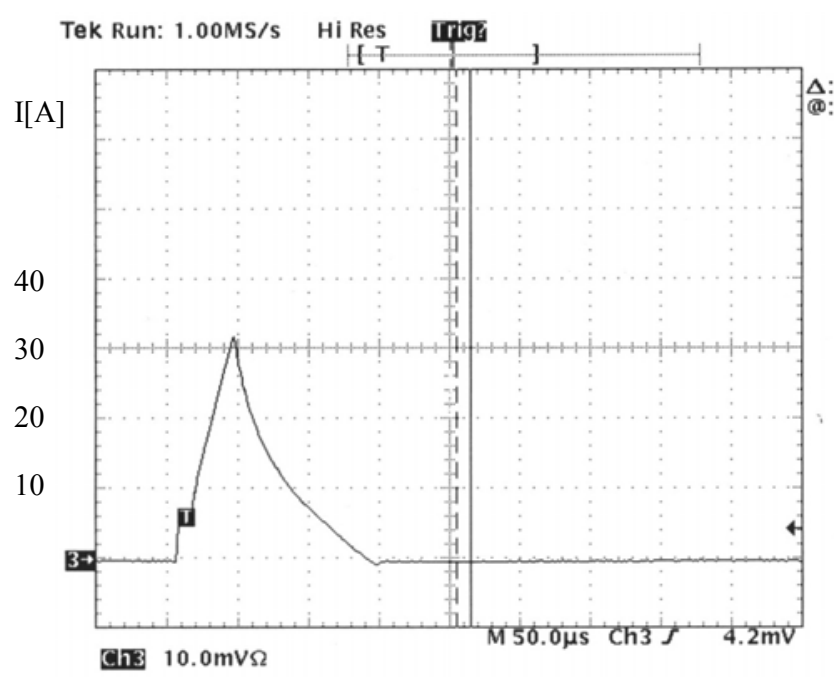

Rys. 5. Prąd przy załączaniu na zwarcie (10A/dz.)

\subsection{Lącznik ŁTN-24}

Do zasilania wentylatorów grzałek podsiedzeniowych, wentylatorów wyciagowych oraz obwodów zabezpieczeń termicznych zastosowano łączniki tranzystorowe typu ŁTN-24 opracowane dla potrzeb omawianej nagrzewnicy w IPS „TABOR”. Ma to na celu zabezpieczenie przed zwarciem wszystkich obwodów napięcia $24 \mathrm{~V}$ wychodzących poza skrzynię nagrzewnicy i wyeliminowanie tym samym konieczności ingerencji serwisu w samej nagrzewnicy. Łącznik ŁTN-24 (rys.6) jest przekaźnikiem półprzewodnikowym z zabezpieczeniem przeciwzwarciowym i przeciwprzepięciowym.

Łącznik jest przeznaczony do pracy w zakresie temperatur od $-30^{\circ} \mathrm{C}$ do $+70^{\circ} \mathrm{C}$. Może załączać prąd do $20 \mathrm{~A}$ dla obciążeń o charakterze indukcyjnym. Zastosowane zabezpieczenie przeciwzwarciowe ma charakter bezpiecznikowy, tzn. po jego zadziałaniu konieczne jest zdjęcie napięcia sterującego i ponowne jego załączenie. Przykładowe przebiegi prądów przy załączaniu obciążenia oraz załączania na zwarcie przedstawiono na rys. 7 i 8 .

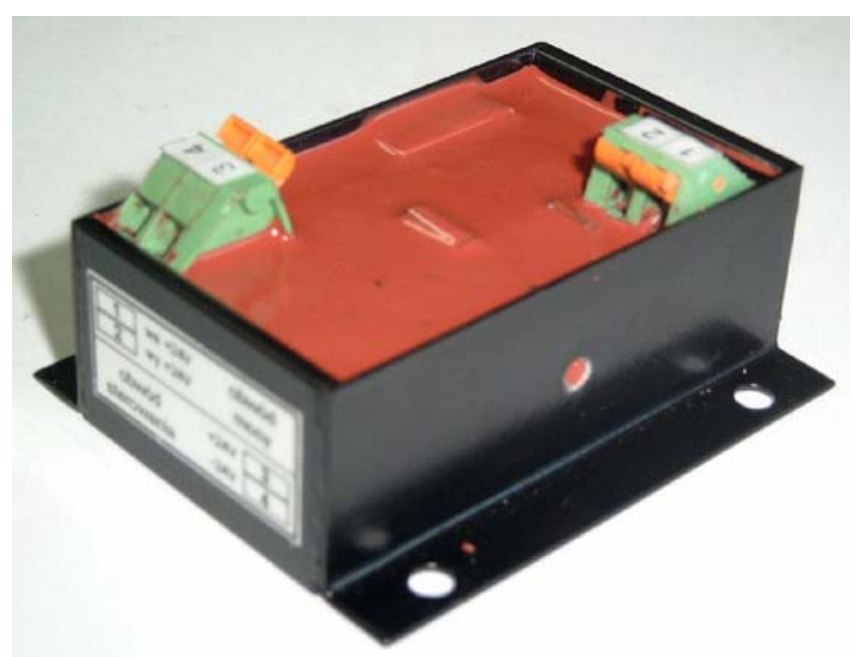

Rys. 6. Widok łącznika ŁTN-24

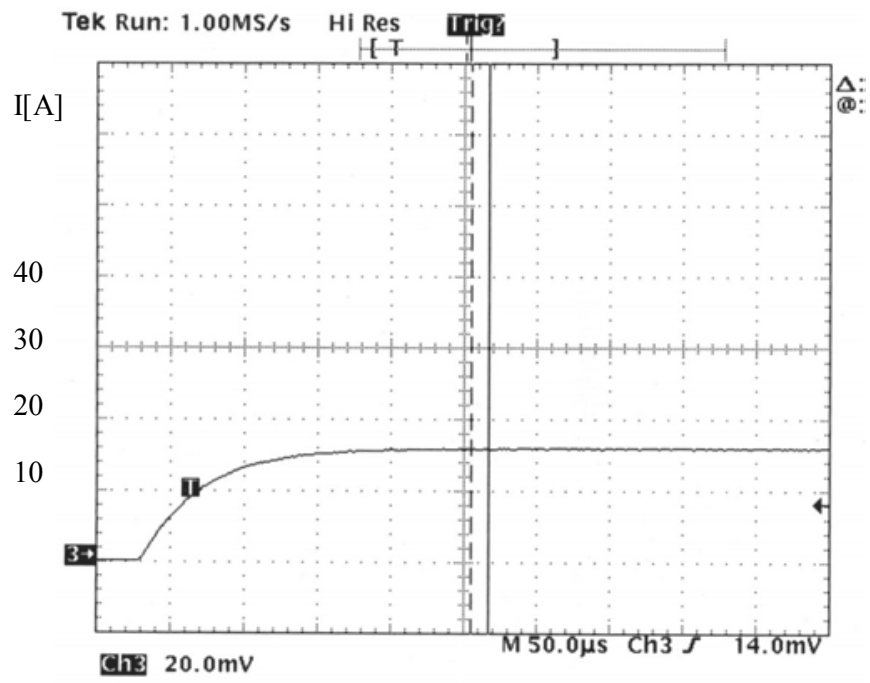

Rys. 7. Prąd przy załączaniu obciążenia 400W (10A/dz.)

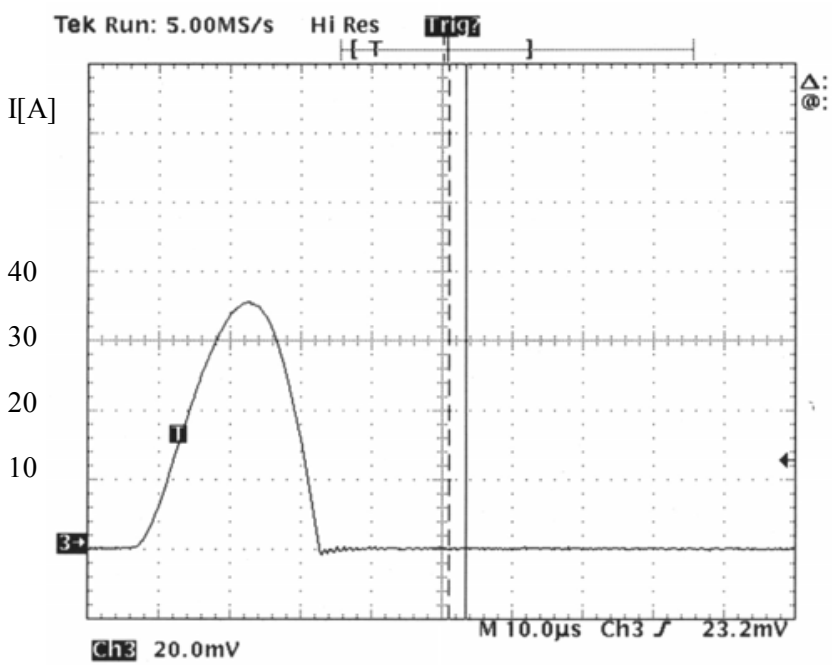

Rys. 8. Prąd przy załączaniu na zwarcie (10A/dz.) 
Wymiary gabarytowe łącznika wynoszą 70 x 60 × 34 $\mathrm{mm}$. Obudowa jest przystosowana do montażu 4 śrubami M4 z rozstawem 50 x $50 \mathrm{~mm}$. Płytka drukowana jest zalana kauczukiem silikonowym.

\subsection{Moduł pośredniczący PCA3-01}

Do sterowania serwonapędu przepustnic powietrza nagrzewnicy skonstruowano w IPS „TABOR” moduł pośredniczący PCA3-01 (rys.9). Jest to 3 kanałowy, 2 bitowy przetwornik c/a. Nie jest konieczne płynne sterowanie stopniem otwarcia przepustnic, wystarczą 3 pozycje. Opisany moduł zastosowano ze względów ekonomicznych, eliminując potrzebę zakupu 2 modułów wyjść analogowych do sterownika mikroprocesorowego.

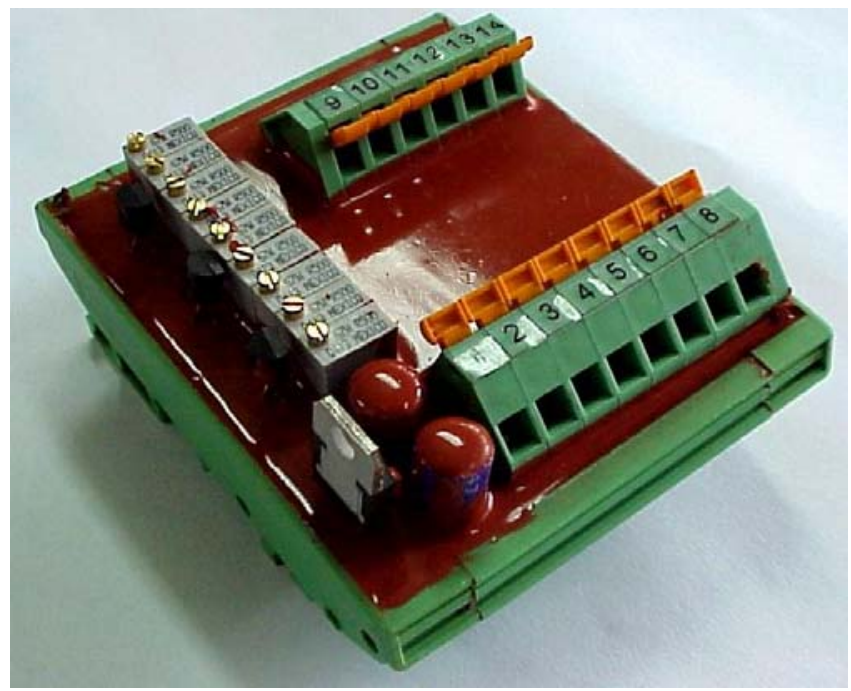

Rys.9. Widok modułu PCA3-01

Moduł PCA3-01 jest przeznaczony do montażu na szynie Ts35 i posiada wymiary gabarytowe $68 \times 82 \times 42 \mathrm{~mm}$. Pracuje w zakresie temperatur od $30^{\circ} \mathrm{C}$ do $+70^{\circ} \mathrm{C}$. Jego wyjścia analogowe są odporne na zwarcie. Całość jest hermetyzowana kauczukiem silikonowym.

\section{Zasilanie}

Do zasilania układów sterujących nagrzewnicy zastosowano opracowane w IPS „TABOR” zasilacze PWZ-04 (rys.10) o mocy 30W. Konstrukcja umożliwia pracę równoległą wielu modułów w zależności od zapotrzebowania. Gwarantują one ciagłość zasilania nawet $\mathrm{w}$ przypadku uszkodzenia przetwornicy. Następuje wówczas automatyczne przełączenie napięcia zasilania na napięcie niestabilizowane $\mathrm{z}$ jednoczesna sygnalizacją awarii (optyczną i elektryczna).

Cechą wyróżniającą jest bardzo szeroki zakres zmian napięcia zasilana od $10 \mathrm{~V}$ do $40 \mathrm{~V}$.

Pozostałe parametry techniczne:

- znamionowe napięcie zasilania (Ucc) $+24 \mathrm{~V}$

- znamionowe napięcie wyjściowe (Uwy)
- prąd obciazzenia

$1250 \mathrm{~mA}$

- zakres temperatur pracy od $-40^{\circ} \mathrm{C} \mathrm{do}+85^{\circ} \mathrm{C}$

- odporność na przepięciawg EN-50/155

- odporność na drgania i wstrząsywg EN-50/155

- obudowa

- zaciski przyłączowe

- wskaźnik uszkodzenia

- w przypadku uszkodzenia profil poliamidowy zaciski sprężynowe dioda LED + styk n.o.

$\mathrm{Uwy}=\mathrm{Ucc}$

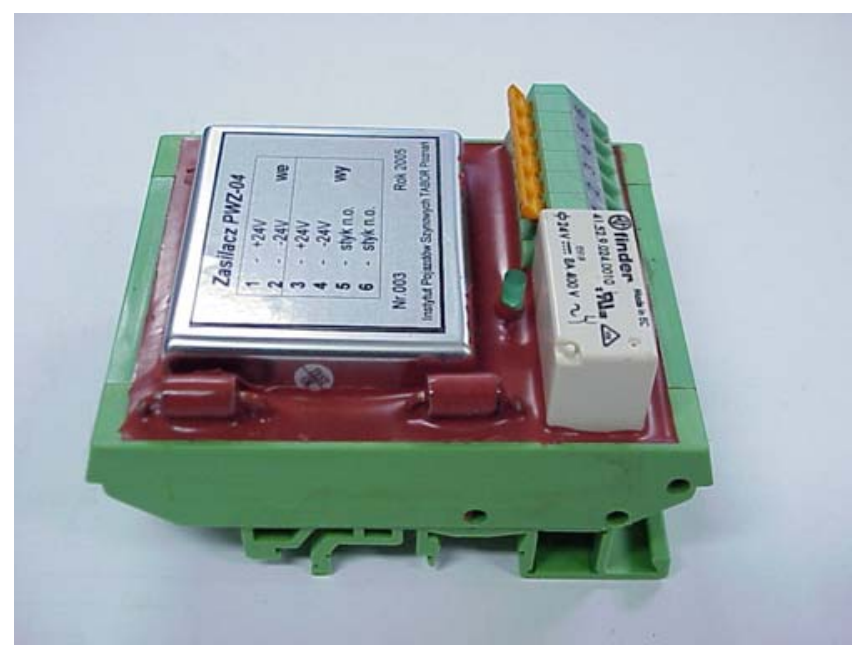

Rys.10. Widok zasilacza PWZ-04

Zasilacz PWZ-04 jest przeznaczony do montażu na szynie Ts35 i posiada wymiary gabarytowe $68 \times 82 \times 42 \mathrm{~mm}$.. Jest odporny na zwarcie. Całość jest hermetyzowana kauczukiem silikonowym

\section{Sterownik mikroprocesorowy}

W zespole zastosowano sterownik mikroprocesorowy firmy Selectron odporny na drgania i przystosowany do pracy w zakresie temperatur odpowiadających wymaganiom trakcyjnym. Jest on zamocowany na płycie (poz.6 na rys.1). Składa się z ośmiu modułów. Są to: 2 moduły wejść cyfrowych - CPU 725 CT i DIT 701 T, 3 moduły wyjść cyfrowych DOT $701 \mathrm{~T}$, 1 moduł wejść analogowych AIT 704 T oraz 2 moduły pomiaru temperatury AIT $702 \mathrm{~T}$.

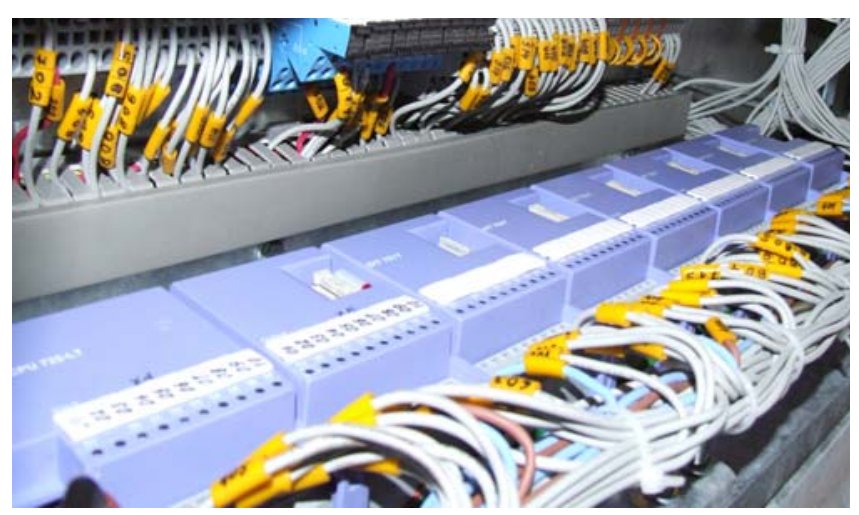

Rys.10. Widok sterownika mikroprocesorowego 
Na wejścia cyfrowe sterownika wprowadzone są następujące sygnały:

- załączenie nagrzewnicy

- temperatura zadana

- rodzaj pracy nagrzewnicy

- sygnały załączenia styczników załączających nagrzewnicę

- sygnały z wyłączników termicznych o nastawie $50^{\circ} \mathrm{C}$

- stan styków presostatów

- sygnał zasilania obwodów termostatowania

- kasowanie sygnału awarii

Sygnały wprowadzone na wejścia analogowe sterownika:

- prądy nagrzewnic w zespole oraz grzałek podsiedzeniowych

- napięcia wysterowania przepustnic powietrza

- sygnał zasilania $\mathrm{z}$ baterii.

Sygnały wprowadzone na wejścia pomiarowe:

- temperatura zewnętrzna

- temperatura we wnętrzu wagonu

- temperatura w kanałach doprowadzających powietrze do wagonu

- temperatura w otoczeniu elementów grzejnych w zespole wentylacyjno-grzewczym.

Sygnały wyjściowe sterujące pracą zespołu:

- załączenie łączników tranzystorowych

- załączenie wentylatorów w zespole

- załączenie wentylatorów wyciagowych

- sterowanie przepustnicami

- zasilanie przepustnic

- sygnały stanu awarii

- temperatura w otoczeniu elementów grzejnych w zespole wentylacyjno-grzewczym.

\section{Diagnostyka}

Sterownik mikroprocesorowy pozwala na identyfikację awarii wyposażenia zespołu. W tym celu zastosowano złącze diagnostyczne, poprzez które w oparciu o oprogramowanie sterownika można uzyskać informacje o pracy zespołu. Dla użytkownika sygnały stanów awarii sterownik przekazuje ponadto do 4 lampek sygnalizacyjnych umieszczonych we wnętrzu wagonu. Rodzaj awarii, który wskazują zaświecone poszczególne lampki określić można według umieszczonego obok lampek wykazu kodów uszkodzeń.

\section{Badania homologacyjne}

Zespół wentylacyjno-grzewczy został poddany badaniom homologacyjnym. Dotychczas pomyślnie zakończyły się następujące próby:

- $\quad$ sprawdzenie rezystancji izolacji

- sprawdzenie wytrzymałości elektrycznej izolacji

- sprawdzenie nagrzewania się zespołu

- sprawdzenie wydajności wentylatorów

W najbliższym czasie przeprowadzone zostaną kolejne:

- próba pracy długotrwałej

- próba odporności izolacji na wilgoć

- sprawdzenie odporności zespołu na drgania mechaniczne.

\section{Wnioski}

Prezentowane rozwiązanie umożliwia dalszą rozbudowę zespołu. Dzięki kompaktowej budowie zespołu istnieje możliwość jego dostosowania do innych typów pojazdów. Ponadto biorąc pod uwagę duże możliwości sterowników mikroprocesorowych, uzasadnione jest rozszerzenie systemu diagnostycznego o oprogramowanie przewidziane dla obsługi serwisowej. Zastosowanie łączników bezstykowych zamiast styczników podnosi niezawodność, trwałość oraz zmniejsza poziom zakłóceń elektromagnetycznych. Zabezpieczenie przed zwarciem wszystkich obwodów napięcia $24 \mathrm{~V}$ wychodzących poza skrzynię nagrzewnicy eliminuje konieczność ingerencji serwisu w samej nagrzewnicy z powodu zwarć w obwodach współpracujących $\mathrm{z}$ zespołem wentylacyjnogrzewczym. 